\title{
EFFECT OF VARYING LEVEL OF FISHMEAL SUBSTITUTION WITH SOYABEAN MEAL ON CERTAIN SERUM METABOLITES AND HAEMATOLOGICAL INDICES IN CHICKENS
}

\author{
V.A. ALETOR and O. OGUNYEMI* \\ Department of Animal Production \& Health, \\ Federal University of Technology, \\ P.M.B. 704, Akure, Nigeria
}

(Received 3 February 1989; accepted for publication 31 March 19890).

\begin{abstract}
The effect of substituting fishmeal protein with soyabean meal protein on serum metabolism and some haematological indices, have been assessed, using Hyperco broiler chickens. Six diets (isonitrogenous and isocaloric) were fed, in which, 0,20 , $40,60,80$ and $100 \%$ of dietary fishmeal (FM) protein was substituted with soyabean meal (SMB) protein.

Results showed significant $(P<0.05)$ differences in clotting time, packed cell volume (PCV), red blood count (RBC) and mean corpuscular volume (MCV), due to dietary treatments. Clotting time was longest for birds on diet 6 in which FM was completely with SMB and shortest for those on diet 3. The variations in the PCV, RBC and MCV followed no particular trend with dietary treatments. The haemoglobin concentration (Hb), mean corpuscular haemoglobin (MCH) and mean corpuscular haemoglobin concentration (MCHC) did not differ significantly $(P>0.05)$.

Total serum protein (TSP), albumin, globulin and albumin/globulin ratio, were not significantly $(P>0.05)$ influenced by the dietary treatments. However, significant $(P<0.05)$ differences were obtained in the serum urea levels as the values seemed to increase with.increasing level of FM substitution with SBM.

It was inferred, that an all-SBM feeding may have serious implications for the routine debeaking processes, especially in layers, given the much higher clotting time for birds on diet 6 in which there was $100 \%$ substitution of FM with SBM protein.
\end{abstract}

Key Words: Fishmeal, Soyabean meal, Serum Metabolites, Haematological Indices, Chicken.

MATERIALS AND METHODS

\section{Animals}

A total of 90 Hyperco broiler chicks, supplied, by Lipakala Farms, (Nig.) Ldd., Ondo, was used for the study. All chicks were housed in a 4-decked electrically heated battery brooder. They were fed a $24 \%$ protein broiler starter diet for a pre- experimental period of 3 weeks and also vaccinated against Newcastle and infectious bursal disease. 


\section{Experimental Design}

At the end of the 3-week pre-experimental period, 15 chickens (in 3 replications of 5 chickens per replicate), were randomly assigned to each of the 6 diets, in which, graded levels of FM protein (0, 20, 40, 6080 and $100 \%$ ), were replaced with SBM protein. All diets were isocaloric and isonitrogenous (Table 1). The experimental diets and clean water were given to the chickens, ad libitum for 5 weeks.

\section{Clotting time}

Clotting time for each of the experimental birds was determined by the capillary tube agglutination method (Schalm, et al.) 1975).

\section{Collection of blood samples}

Blood samples were obtained, terminally from the chicks, by neck decapitation. The sample from each bird was collected into labelled EDTA bottle and clean test tubes. The blood samples in the EDTA bottles, were processed for haematology, while samples in the test tubes, were refrigerated for about 6 hours, after which, the serum separated out clearly.

\section{Haematology}

Percent packed cell volume (PCV) was determined, by spinning about $75 \mu$ of each blood sample in heparinized capillary tubes, in a haematocrit microcentrifuge for 5 minutes, while total red blood count (RBC) was estimated, using normal saline as the diluting fluid. The haemoglobin content of the blood was estimated (Swensen, 1951). The mean corpuscular volume (MCV), mean corpuscular haemoglobin (MCH) and mean corpuscular haemoglobin concentration (MCHC), were calculated as described by Green (1976).

\section{Biochemical measurements}

The following parameters were measured colorimetrically with SIGMA assay kits: Total serum protein (TSP) and serum urea. Total albumin and globulin, were also determined colorimetrically (Lamb, 1981).

The data were subjected to factorial analysis of variance with an IBM/PC micro computer, and where treatment means were significant, they were compared, using the Duncan's multiple range test (Steel and Torrie, 1960).

\section{RESULTS}

\section{Clotting time and haematology}

The effect of fishmeal substitution with soyabean meal, on the haemogramme of the broiler chicken, is presented in Table 2 . Significant differences $(P<0.05)$ were recorded, in the clotting time, PCV, RBC and MCV values of chicks on different diets, in which SBM replaced FM. Clotting time was longest for the blood samples recovered from chicks placed on all-SBM diet (diet 6) and shortest for samples from birds on diet 3. The variation in the PCV, RBC and MCV followed no particular trend with the dietary treatment. The haemoglobin concentration $(\mathrm{Hb}), \mathrm{MCH}, \mathrm{MCHC}$, of birds on the various diets, did not differ significantly $(P>0.05)$.

\section{Serum Biochemistry}

The mean values \pm standard deviation (SD) of the TSP, albumin, globulin, albumin/globulin ratio, are presented in Table 3 . There were no significant $(P>0.05)$ differences in the serum levels of these variables, due to the dietary treatments. However, significant differences $(\mathrm{P}<0.05)$ were recorded in the blood urea level of the chicken, on the various diets (Table 3). There was a tendency for the values to increase with increasing FM substitution with SBM. 
Table 1

Gross and proximate composition of experimental diets

DIETS

$\begin{array}{llllll}1 & 2 & 3 & 4 & 5 & 6\end{array}$

\% FM protein replaced by SMB protein

\begin{tabular}{|c|c|c|c|c|c|c|}
\hline INGREDIENTS & 0 & 20 & 40 & 60 & 80 & 100 \\
\hline Maize & 55.85 & 55.37 & 54.89 & 54.41 & 53.93 & 53.45 \\
\hline Groundnut Cake & 28.00 & 28.00 & 28.00 & 28.00 & 28.00 & 28.00 \\
\hline Fishmeal $^{\mathrm{a}}$ & 5.00 & 4.00 & 3.00 & 2.00 & 1.00 & 0.00 \\
\hline Soyabean meal ${ }^{b}$ & 0.00 & 1.48 & 2.96 & 4.44 & 5.92 & 7.40 \\
\hline \multicolumn{7}{|l|}{ Brewer's Dried } \\
\hline grain & 5.00 & 5.00 & 5.00 & 5.00 & 5.00 & 5.00 \\
\hline Palm oil & 2.00 & 2.00 & 2.00 & 2.00 & 2.00 & 2.00 \\
\hline Bone meal & 2.50 & 2.50 & 2.50 & 2.50 & 2.50 & 2.50 \\
\hline Oyster shell & 0.50 & 0.50 & 0.50 & 0.50 & 0.50 & 0.50 \\
\hline DL-Methionine & 0.15 & 0.15 & 0.15 & 0.15 & 0.15 & 0.150 \\
\hline Premix & 0.50 & 0.50 & 0.50 & 0.50 & 0.50 & 0.50 \\
\hline Salt & 0.50 & 0.50 & 0.50 & 0.50 & 0.50 & 0.50 \\
\hline \multicolumn{7}{|l|}{ Calculated: } \\
\hline Crude protein $(\%)$ & 22.39 & 22.34 & 22.29 & 22.24 & 22.20 & 22.20 \\
\hline M.E. (Mcal Kg ${ }^{-1} \mathrm{DM}$ ) & 3.07 & 3.07 & 3.07 & 3.06 & 3.06 & 3.06 \\
\hline \multicolumn{7}{|l|}{ Methionine } \\
\hline Cystine (\%) & 0.89 & 0.88 & 0.87 & 0.86 & 0.85 & 0.84 \\
\hline Lysine (\%) & 1.16 & 1.15 & 1.14 & 1.13 & 1.13 & 1.13 \\
\hline \multicolumn{7}{|c|}{ Proximate chemical comp.osition (\%) } \\
\hline Crude protein (CP) & 22.15 & 22.29 & 22.43 & 22.59 & 22.77 & 22.47 \\
\hline Crude fibre (CF) & 3.80 & 4.26 & 3.98 & 3.72 & 3.92 & 3.86 \\
\hline Ether extrace (EE) & 4.62 & 5.01 & 4.93 & 4.22 & 5.11 & 4.62 \\
\hline Ash & 5.12 & 5.96 & 6.00 & 5.82 & 5.99 & 5.13 \\
\hline Moisture & 5.32 & 6.28 & 5.76 & 6.32 & 6.68 & 4.12 \\
\hline Nitrogen-fre & & & & & 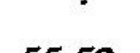 & \\
\hline extract (NFE) & 58.97 & 56.20 & 56.90 & 57.28 & 55.53 & 59.80 \\
\hline Dry matter (DM) & 94.67 & 93.71 & 94.23 & 93.67 & 93.31 & 95.87 \\
\hline
\end{tabular}

a Contained C.P. 65\%, CF 1.00\%, EE 3.83\%, Ash 14.29\%, Moisture $7.56 \%$, NFE 8.35\%, DM $92.44 \%$.

b Contined CP $43.88 \%$, CF $5.52 \%$, EE $4.11 \%$, Ash $5.07 \%$, Moisture $9.88 \%$, NFE $31.54 \%$, DM $90.22 \%$. 


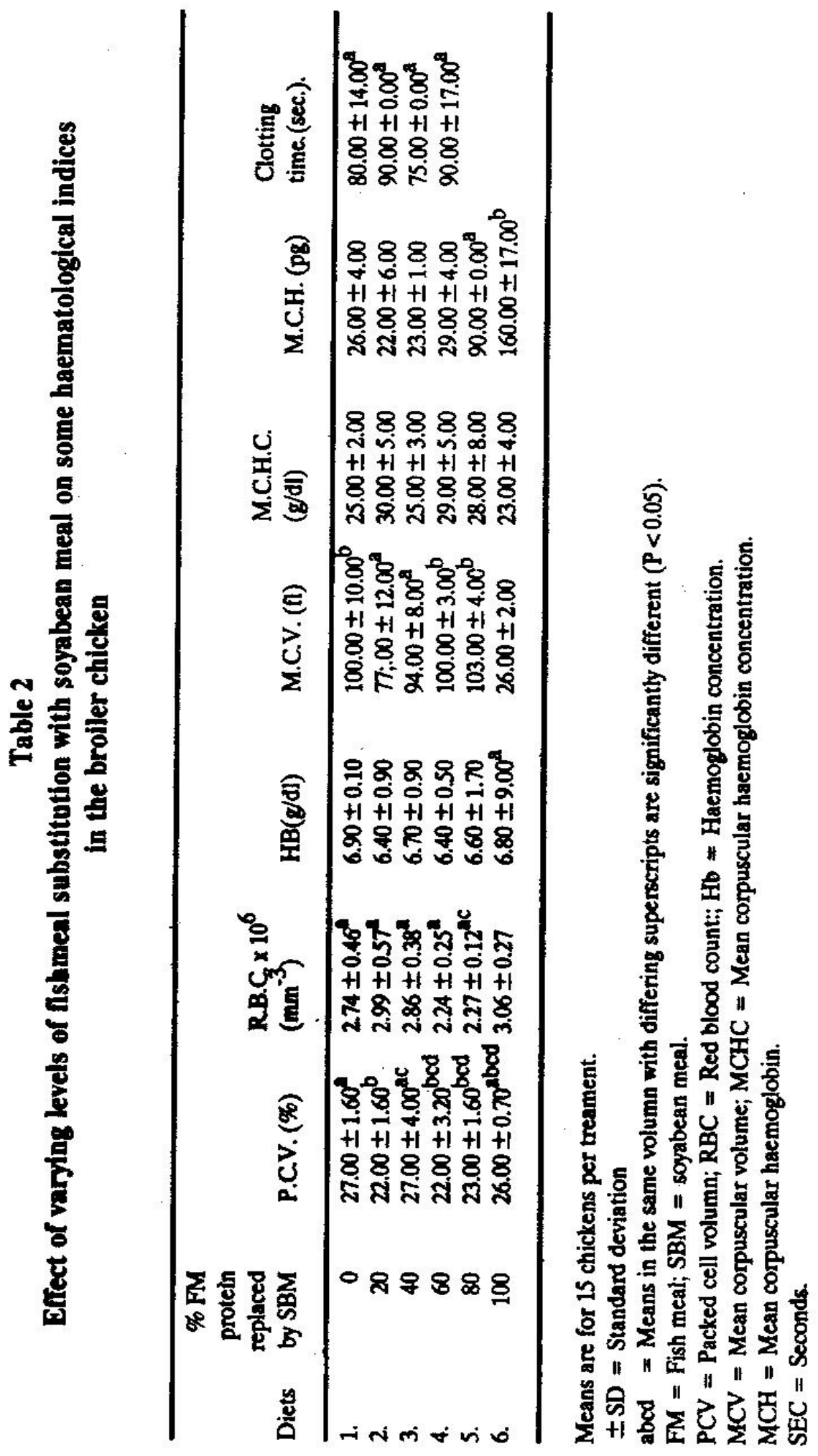


Table 3

Efiect of varying levels of fishmeal substitution with sojabean meal on some serum metabolites in the broiler chicken

\begin{tabular}{|c|c|c|c|c|c|}
\hline $\begin{array}{r}\% \text { FM } \\
\text { protein } \\
\text { replaced } \\
\text { Diets by SBM }\end{array}$ & $\begin{array}{l}\text { TSP } \\
(\mathrm{g} / 100 \mathrm{ml})\end{array}$ & $\begin{array}{l}\text { (ALBUMIN } \\
\text { (g/100ml) }\end{array}$ & $\begin{array}{l}\text { CLOBULIN } \\
(\mathrm{g} / 100 \mathrm{ml})\end{array}$ & $\begin{array}{l}\text { ALBUMIN/ } \\
\text { GLOBULIN }\end{array}$ & $\begin{array}{l}\text { UREA } \\
\text { (mg/100ml) }\end{array}$ \\
\hline 1. & $3.26 \pm 0.11$ & $2.04 \pm 0.19$ & $1.22 \pm 0.08$ & $1.68 \pm 0.27$ & $24.45 \pm 2.23^{c}$ \\
\hline 20 & $3.18 \pm 0.11$ & $1.79 \pm 0.09$ & $1.44 \pm 0.33$ & $1.29 \pm 0.31$ & $26.45 \pm 0.38^{b c}$ \\
\hline 40 & $3.04 \pm 0.13$ & $1.91 \pm 0.03$ & $1.14 \pm 0.14$ & $1.70 \pm 0.23$ & $25.56 \pm 3.34^{c}$ \\
\hline 60 & $3.15 \pm 0.33$ & $1.91 \pm 0.13$ & $1.35 \pm 0.28$ & $1.47 \pm 0.34$ & $28.89 \pm 1.92^{2 b c}$ \\
\hline 80 & $3.04 \pm 0.11$ & $1.86 \pm 0.04$ & $1.18 \pm 0.13$ & $1.59 \pm 0.20$ & $30.74 \pm 0.64^{\mathrm{ab}}$ \\
\hline 100 & $3.11 \pm 0.12$ & $1.94 \pm 0.09$ & $1.28 \pm 0.05$ & $1.65 \pm 0.06$ & $31.69 \pm 0.87^{\circ}$ \\
\hline
\end{tabular}

Means are for 15 chickens/diett.

\pm SD = standard deviation.

$a b c=$ Means in the same column with differing superscripts are significantly different $(P<0.01)$.

TSP $=$ Total serum protein

SBM = Soyabean meal.

\section{DISCUSSION}

The present study showed that, replacement of FM protein with SBM protein, in the diet of the broiler chicken, had no effect on the $\mathrm{Hb}, \mathrm{MCH}$ and MCHC. The study further suggests that haemoglobin synthesis, progressed normally in birds, even when all the dietary protein was of plant origin. Dietary replacement of FM with SBM did not also, significantly affect the TSP, albumin, globulin and albumin, globulin ration. Wright (1971) opined that protein from muscle and viscera (animal origin) favour albumin formation, while protein from other sources (plant and grains) favour globulin formation. Although, significant differences were not recorded with respect to these fractions, a comparison of the values for birds on the all-fishmeal diet (diet 1) and all soyabean meal diet (diet 6) tends to support this assertion. it has also been observed
(Wright, 1971) that if given intravenously, plasma or serum protein can supply all the tissue needs for protein, and that, food protein can then be temporarily dispensed with; thus suggesting that plasma protein can readily be incorporated into the tissues. Similarly, Eggum (1976) and Tewe (1985) reported a positive linear correlation between protein quality and total serum protein concentration and; a negative correlation between serum urea and creatinine concentrations. Although no correlation analysis was carried out, significant differences were recorded in the serum urea; with the values increasing with increasing level of FM replaced with SBM. This observation tends to suggest poorer dietary protein quality as the level of substitution of FM protein with SBM protein increases.

Although treatment effects on PCV, RBC and MCV were significant, values were however within the normal ranges for chick- 
ens. Antibodies formed by lymphocytes and plasma' cells, in response to infection, are known to be found, mainly, in the globulin fraction of serum or plasma protein. Since this fraction was relatively similar in all the dietary treatments, it is probable that, replacing FM with SBM in poultry diet, may not have any serious immunological implications. Of much interest, haematologically, is the considerably higher clotting time for birds on all-SBM diet (diet 6; Table 2) than for chickens on other treatments. It is however left to be elucidated, whether soyabean contains any agent(s), that interfere with clotting mechanism, since clotting time is a test of the clotting mechanism, especially the amount of thromboplastin formed. Such delayed clotting time holds serious implications for the routine de-beaking processes, particularly in layers; and when soyabean is used as a major source of dietary protein.

\section{ACKNOWLEDGEMENT}

We acknowledge, with thanks, the Senate Research Committee, Federal University of Technology, Akure, for an extension of an initial grant to undertake this study. We are also grateful to Mr. Sunny Ovienria of the Department of Mining Engineering and $\mathrm{Mr}$. Emma Ukonu, of the Department of Animal Production and Health, for typing the manuscripts.

\section{REFERENCES}

EGGUM. B.O., (1976). Protein Metabolism and Nutrition (Cole, T.A., Boorman,. K.N., Buttery, P.J., Lewn, D.; Nale, R.J. and Wan, H.S.; Editors), London, Butterworth, 249-258pp.

IKURIOR, S.A., and FETUGA, B.L., (1985). The replacement value of Nigerian cottonseed cake for groundnut cake in the diets for weanergrower pigs. Nig. J. Anim. Prod. 12 (1): $13-19$.

LAMB, G.M., (1981). Manual of Veterinary Laboratory Techniques (Lamb, G.M. Editor). CIBA-Geigy, Kenya, 102 115.pp.

OFFIONG, S.A., OLOMU, J.M., DAFWANG, I and ABED, E. (1982) The replacement value of blood meal for fishmeal in diets of broilers in the tropics. J. of Anim. Prod. Res. 2 (2): $131-151$.

SCHALM, O.W., JAIN, N.C. and CARROL, E. J. (1975). In: Veterinary Haemetology, 3rd edition, Lea and Febiger, Philadelphia, Pg. 55.

STEEL, R.G.D. and TORRIE, J.H., (1960). Principles and procedures of Statistics, McGraw-Hill Book Co. Inc. New York.

SWENSEN, M.T., (1951). Effect of a vitamin $B^{12}$ and liver meal on the haematology of chicks fed on allprotein ration. Am. J. Vet. Res. 12: 147151.

TEWE, O.O., (1985). Protein metabolism in growing pigs fed corn or cassava peel based diets containing graded protein levels. Res. Vet. Sci. 38: 259-263.

WRIGHT, S., (1971). Samson Wright's applied Physiology (Keele, C.A. and Neil, C. Editors) 12th edition, Oxford University Press, London, Pg. 16. 